Full length research article

\section{THE EFFECTS OF CATHARANTHUS ROSEUS (L) G. DON 1838 AQUEOUS LEAF EXTRACT ON SOME LIVER ENZYMES, SERUM PROTEINS AND VITAL ORGANS}

*JAMES S. A1 , BILBISS L. ${ }^{2} \&$ MUHAMMAD B. Y. ${ }^{3}$

${ }^{1}$ Department of Biochemistry

Kaduna State University, Nigeria

${ }^{2}$ Department of Biochemistry

${ }^{3}$ Department of Pharmacology, College of Health Science

Usmanu Danfodiyo University, Sokoto Nigeria.

${ }^{*}$ Corresponding author

(sjgamong@yahoo.com).

\begin{abstract}
Plant and phytochemical products continue to play an important role in medicine. In this study, the toxicological potentials of the aqueous leaf extract of Catharanthus roseus G. Don 1838 in rabbits were determined. The rabbits were placed in three groups with four rabbits in each group. The control group, a second group administered with $100 \mathrm{mg} / \mathrm{Kg}$ and third group administer with $360 \mathrm{mg} / \mathrm{Kg}$ body weight, were tag as Group 1, 2 and 3 respectively. Increased levels of serum alanine transaminase (ALT), aspartate transaminase (AST) and alkaline phosphatase (ALP) were found to follow the treatment of rabbits with ACR suggesting liver damage. This was confirmed by the histopathological studies that reveal centrieolobular hemorrhagic necrosis of the liver. Also, there was oxidative glomerulonephritis that set in. The effect of the extract in the activity of the hepatocellular enzymes (ALT, AST, and ALP) was found to be concentration dependent. This suggest that the infusion of the leaves could cause hepatocellular damage and kidney impairment.
\end{abstract}

Keywords: Catharanthus roseus, Aqueous Leaf extract, Toxicity, Alkaloids, Enzymes levels.

\section{INTRODUCTION}

The plant Catharanthus roseus (L) G. Don 1838 (Periwinkle or Vinca) has gained acceptance from the pharmaceutical industries as it is widely used as an infusion in different parts of world to treat diabetes (Ratsumamanga 1980; Audu 1989; Alexandrova et al. 2000; Heijden et al. 2004). Experimental evidence shows that the concentrated aqueous extract can lower blood-sugar level in rats, reduce the symptoms of diabetes and as hemostatic and tranquilizer to lower blood pressure in man and as a disinfectant (Marton 1977; Wikipedia 2006). Although attempts to confirm the active principles have met with little success, information is now available about its anti-leukemic properties (Sim 1971; Taylor and Farnsworth 1973; Alexandrova et al. 2000). Out of almost 6000 known alkaloids isolated from plants, more than 70 are from $C$. roseus (Sofowora 1982; Miller; 1973; Harbone 1991; Heijden et al. 2004).

Available literature on Cathranthus only indicated the toxic effects of the synthetic alkaloids and the cytotoxic effects of the crude extract on cell division, damage on the nerves which control digestion, bowels, cardiac and sexual function (Lobert et al. 1997; Alexandrova et al. 2000; Khan 2007). As the possibility of the impairment of vital organs by the crude extract of this plant when consumed cannot be ruled out, it becomes necessary to investigate the levels of the bilirubin hepatic enzymes and other blood constituents that could be affected. This Study was carried out to monitor the effect of the aqueous leaf extracts of $C$. roseus on some liver enzymes, serum protein on heart, kidney and liver.

\section{MATERIALS AND METHODS}

Plant material: Fresh leaves of $C$. roseus were collected from flower beds. The leaves were rinsed with water, sun-dried and crushed to powder with mortar and pestle and stored in a dry clean plastic bottle. $50 \mathrm{~g}$ of the powdered form was soaked into $500 \mathrm{ml}$ of boiling distilled water. The mixture was allowed to infuse for one hour with constant stirring. The mixture was filtered with a cloth sieve followed by cotton wool. The concentration of the aqueous extract was determined in weight per volume.

Experimental animals: 12 New Zealand breed of rabbits were randomly divided into three replicates and a control group and subjected to the following treatments:

Group 1: Control animals were allowed access to water only Group 2: Animals given $100 \mathrm{mg} / \mathrm{kg}$ body weight dose of the extract and water.

Group 3: Animals given $360 \mathrm{mg} / \mathrm{kg}$ body weight of the extract and water.

Feeding was done ad libitum with pelleted animal feeds. The extracts of $C$. roseus were administered orally with the aid of a plastic syringe for 9 days according to the body weight of each rabbit (Williams 1976).

Blood sample collection: Blood was collected from the experimental animals by venopuncture via the jugular vein into two sets of tubes. Into one of the tubes containing sodium citrate as anticoagulant, $10 \mathrm{ml}$ of the blood was added and mixed thoroughly by inverting the tubes. The mixed blood was then centrifuged at $3000 \mathrm{~g}$ for $10 \mathrm{~min}$, and the plasma transferred to another tube. Blood serum was prepared by allowing $10 \mathrm{ml}$ of blood into each tube without anticoagulant to stand for $10 \mathrm{~min}$, and centrifuged for five min at $3000 \mathrm{~g}$. The sera obtained was transferred into a sample vials and stored in the refrigerator.

Toxicological tests: Estimation of prothrombin time: One stage method (Quicks 1970) was used based on the activation of factors VII, V, X, II and I as excess preformed extrinsic thromboplatins, thereby passing factors XII, XI, IX and VIII. (Raphael 1983). $0.2 \mathrm{ml}$ of thromboplastin calcium chloride reagent was added into a test tube and incubated with the tube containing portion of the plasma at $37^{\circ} \mathrm{C}$ in water bath for $1 \mathrm{~min}$. A minute later, $0.1 \mathrm{ml}$ of plasma was blown into it, and a stopwatch started simultaneously. The mixture was shaken and left in the water bath for $7 \mathrm{sec}$ at $37^{\circ} \mathrm{C}$. The tested tube was removed from the water bath and tipped gently until a clot was 
formed. Immediately the clot was observed, the stopwatch was stopped, and the time noted. Same was repeated for other samples.

Determination of total serum protein: Biuret method (Doumas 1975 and the absorbance compared with a known protein concentration (Linne \& Ringsurd 1979; Raphael 1983).

Determination of plasma albumin: The Dye binding method (put Ref) was employed, where Bromocresol green react with albumin in an acid solution to yield a blue-green colour complex that absorbs light at $628 \mathrm{~nm}$.

Estimation of globulin: Serum globulin concentration was estimated in $(\mathrm{g} / 100 \mathrm{ml})$ by subtracting the albumin concentration from the serum total protein.

Determination of albumin/globulin ratio: The albumin to globulin ratio was calculated by dividing the albumin value by that of globulin.

Estimation of aspartate amino transferase (AST): Aspartate Amino Transferase (E.C: 2.6.1.1) was estimated by monitoring the concentration of oxaloacetate hydrazine formed with 2,4 dinitrophenyl hydrazine (DNPH) (Raphael 1983).

Estimation of alanine amino transfrase (ALT): The estimation of Alanine amino transferase (E.C: 2.6.1.2) was done by monitoring the concentration of pyruvate hydrazones formed with 2,4 - dinitrophenyl hydrazine (DNPH) (Raphael 1983).

The procedure of estimation of ALT is same as that of AST except for the end substrate, where alanine substrate was used.

Estimation of serum alkaline phosphates (ALP): This was determined using the method of Basssey-lowery \& Brock (1946) as cited by Raphael (1983), where enzyme alkaline phosphates (ALP) hydrolyzes the P-nitrophenyl phosphate substrate, producing inorganic phosphate and p-nitrophenol. The absorbance of the colour was measured photometrically and the concentration determined.

Histopathology test: Histopathology test was conducted on the heart, liver and kidney according to Thompson (1966).

\section{RESULTS}

The aqueous leaf extract exerts a significant $(P<0.05)$ elevation on ALT, AST and alkaline phosphatase (Table 1), while studies on prothrombin time, total protein, serum albumin, globulin and Albumin/Globulin rations shows no significant elevation $(P<0.05)$ (Table 2).

Histological studies carried out on the heart, liver and kidney to ascertain the toxic effect of Catharanthus roseus on these organs revealed the on set of centriobular hemorrhagic necrosis in the liver (Plate 1B). The heart shows no visible changes, while the kidney shows an oxidative glomerulonephritis that have set in within the Bowman's capsule, with few serum fibrins, neutrophils and with extracapillary proliferative reaction (Plate 2B).

\section{TABLE 1: EFFECTS OF AQUEOUS LEAF EXTRACT OF C. ROSEUSON SERUM ENZYME LEVELS.}

\begin{tabular}{lccc}
\hline Parameters & Group 1 & Group 2 & Group 3 \\
\hline ALT (GPT) IU/L & $15.64 \pm 0.36$ & $18.94 \pm 4.7^{*}$ & $24.25 \pm 4.82^{*}$ \\
AST (GOT) IU/L & $14.14 \pm 0.73$ & $17.65 \pm 5.25^{*}$ & $17.5 \pm 2.18^{*}$ \\
Alkaline Phosphate IU/L & $18.0 \pm 2.16$ & $18.0 \pm 0.6$ & $22.0 \pm 4.58^{*}$ \\
\hline The values represent mean ( $\pm \mathrm{SD}), \mathrm{n}=4$ \\
* Significant difference from the control (P<0.05) (paired test). \\
f Group 1: Control animals were allowed access to water only \\
Group 2: Given 100mg/kg body weight dose of the extract \\
Group 3: Given 360mg/kg body weight dose of the extract
\end{tabular}

\section{TABLE 2: EFFECTS OF AQUEOUS LEAF EXTRACT OF} C. ROSEUS ON THE PROTEIN LEVELS.

\begin{tabular}{lccc}
\hline \multicolumn{1}{c}{ Parameters } & Group 1 & Group 2 & Group 3 \\
\hline Prothrombin Time (Sec.) & $9.13 \pm 0.09$ & $8.0 \pm 0.00$ & $10.62 \pm 0.42$ \\
Serum Total Protein $(\mathrm{g} / 100 \mathrm{ml})$ & $8.4 \pm 90.26$ & $8.28 \pm 0.54$ & $8.8 \pm 80.84$ \\
Serum Albumin $(\mathrm{g} / 100 \mathrm{ml})$ & $4.26 \pm 0.69$ & $3.29 \pm 0.03$ & $4.58 \pm 0.35$ \\
Globulin $(\mathrm{g} / 100 \mathrm{ml})$ & $4.23 \pm 0.43$ & $4.99 \pm 0.51$ & $4.3 \pm 0.49$ \\
A/G Ratio & $1.01 \pm 1.60$ & $0.66 \pm 0.10$ & $1.07 \pm 0.70$ \\
\hline
\end{tabular}

NB: The value represent mean $( \pm S D), n=4$

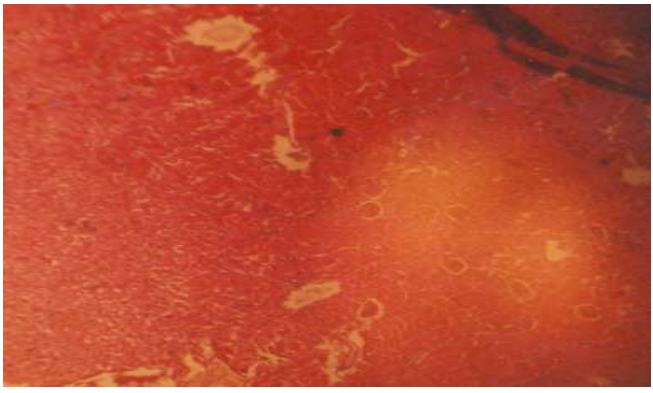

Plate 1A (Liver): Histopathological view of control group with no visible changes

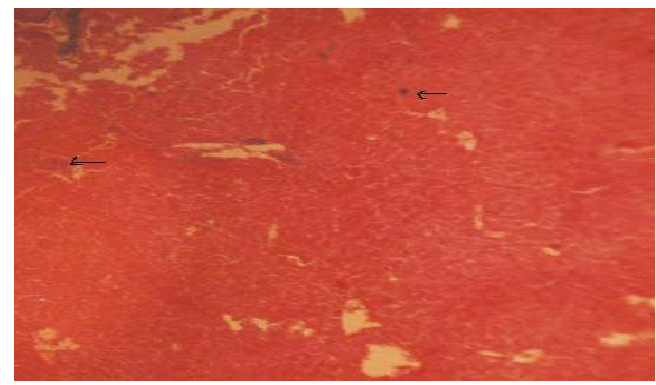

Plate 1B (Liver): Histopathological view of treated group indicating the occurrence of necrosis of sinusoidal lining with the presence of chronic passive congestion, characterized with fibrosis around the control rein. 


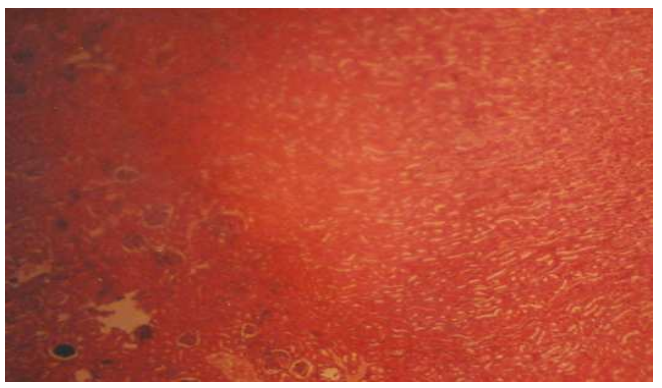

Plate 2A (Kidney): Histopathological view of control group with no visible changes

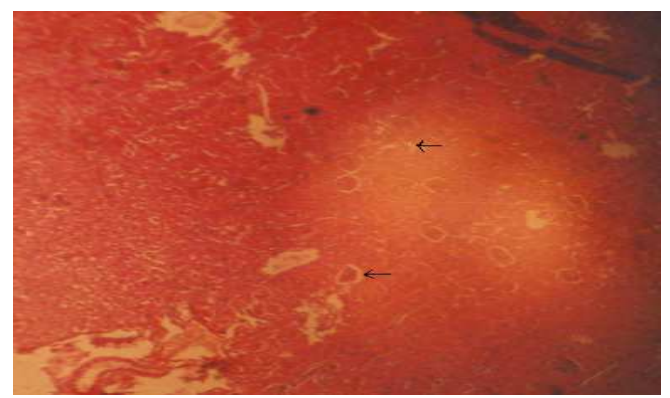

Plate 2 B (Kidney):Treated Group indicating that oxidative glomeralonephritis have set within the Bowman's capsule, with few serum fibrin, neutrophils and extracapillary proliferative reaction

\section{DISCUSSIONS}

Medicinal plants are part of Africa's cultural heritage and a very significant part of present day ailment remedies. Their medicinal benefits and toxic properties are being evaluated for the benefit of mankind (James et al. 2006).

Alkaline phosphatase is a membrane bound enzyme that is released in serum following a pathological phenomenon (Batt \& Siest 1980; Siet et al. 1980). A high increase in serum alkaline phosphatase is a sensitive index of cholestasis, while a minimal increase is indicative of chronic hepatocellular disease (Wilkinson 1976). Alanine amino transferase is a cytoplasmic enzyme found in very low concentration in the liver which is released into the plasma following hepatocellular damage. The increase in concentration of this enzyme, as observed in this study suggests the hepatotoxic effect of the aqueous extract of $C$. roseus. Similar observation was made by Pinkerton et al. (1988) who tested a continuous infusion of $C$. roseus alkaloid Vincristine and found a transient increase in liver enzymes with no elevation of bilirubin. Similarly, results of this study showed no significant elevation of prothrombin, total protein, serum albumin, globulin and Albumin/Globulin rations, agreeing with the findings of Pinkerson et al. (1988). et al. (1988).
Histological studies revealed centriobular hemorrhagic necrosis in the liver (Plate 2B) as expressed in acute toxicity of alkaloids like pyrrolizidine (Mattocks 1972), which is widely distributed in plants (Vickery \& Vickery 1981). Pyrrolizidine alkaloids are hepatotoxic which could damage the liver and result in death in both man and animals (Vickery \& Vickery 1981). One of the toxic effects of pyrrolizidine is venoocclusive liver disease (Mattocks 1968). The toxicity of alkaloids is primarily due to their metabolites produced by biotransformation, and not by the alkaloids themselves (Mattocks 1972). Bull et al. (1968) had earlier reported that pyrrolizidine alkaloids must possess the 1-hydroxymethyl pyrrolizidine system, unsaturated in the 1, 2 - position and a hydroxyl group for esterification before the toxicity can be observed. Another possible reason for the toxic effect may be due to the very slow excretion rate and liver metabolism of $C$. roseus extract which makes the alkaloid to linger in the body (Khan 2007). The histopathological studies on the liver supports this view, as the liver tissue (Plate 1B), shows that necrotic process have set in, while the kidney reveals oxidative glomerulonephritis within the Bowman's capsule, with few serum fibrin, neutrophils and with extracapillary proliferative reaction.

Another toxic effect associated with $C$. roseus alkaloids as reported by Rosazza et al. (1992) include selective reversible inhibition of monoamine oxidase-B (MAO-B) that is important in the biotransformation of xenobiotic. In addition, alkaloids have been found to decrease red blood cells and the formation of granulocyte and leukocytes giving rise to bone marrow depression and neurotoxicity (Barnett et al. 1978; Lobert et al. 1998; Alexandrova et al. 2000; James et al. 2006 \& Khan 2007).

The results from these studies indicate that the use of the aqueous leaf extract of $C$. roseus as infusion for disease remedy may result to hepatocellular damage when consumed in large doses. Consequently, safety measures have to be taken in the administration of these extracts that may include monitoring of the vital serum enzyme levels, administering of milk (for casein to fix alkaloid) as the alkaloids in Catharanthus are found to interact and be resisted by multi-drug resistance associated protein (MRP) (Khan 2007). In addition, vitamin E (an antioxidant) could be administered to further reduce the toxicity and keep cell membrane of tissues and organs intact.

\section{REFERENCES}

Alxeandrova, R; Alxeandrova, I; Velcheva, M. \& Varadino, T 2000. Phytoproducts and cancer. Experimental Pathology and Parasitology 4: 15-25

Audu, J. A. 1989. Medicinal herbs and their uses in Bauchi State. The Nigeria Field 54(Part 3-4): 157-168.

Batt, A. M. \& Siest, G. 1980. Laboratory test as indirect indicators of the activity of drug metabolizing enzymes: use of- 
glucaric acid and gamma-glutamyltransferase."In Drug Effects on Laboratory Results", Siest, G. (ed) Martins Nijhoff PublicationLondon.

Barnett, C. J; Cullinan, G. J; Gerzon, K; Hoying, R. C; Jones, W. E; Newlon, W. M; Poore, G. A; Robison, R. L; Sweeney, M. J. \& Todd, G. C. 1978. Structure-activity relationships of dimeric Catharnthus alkaloids. 1-Deacetylvinblastine amide (vindestine) sulfate. Journal of Medicinal Chemistry 21(1): 88-112

Bessey, O.A. \& Brock, M.J. 1947. Method for rapid determination of alkaline phosphatase with 5 cubic millimeter of serum. Journal of Biological Chemistry 164:321-329

Bull, L. B; Culvenor, C. C. J. \& Dick, A. T. 1968. The Pyrrolizidine alkaloids, North Holland Publishing Company, Amsterdam.

Clapham, A. R. Tutin, T. G. \& Warburg E. F. 1962. Flora of the British Isles, Cambridge University Press, Great Britain

Doumas, B.T. 1975. Standards for total serum protein assays A collaborative study. Clinical Chemistry 98: 1159-1166

Harborne, J. B. 1991. Phytochemical method: A guide to modern techniques of plant analysis $2^{\text {nd }}$ ed. Chapman and Hall, Longman.

Heijden, R. V. d; Jacobs, D. I; Soneijer, W; Hallard, D. \& Verpoorte, R. 2004. The Catharanthus Alkaloids: Pharmcognosy and Biotechnology. Current Medicinal Chemistry 11(5): 607-628

Iwu, M. M. 1993. Handbook of Africa Medicinal Plants. CRC Press London.

James S. A., Bilbis S. L. \& Muhammad, B. Y. 2006. Phytochemical studies and Antibacterial activity of aqueous leaf extract of Cathatanthus roseus. Standardizer of Nigerian Academic Vol. 2 No. 2: 111-119

Khan, H. 2007. Vinca alkaloids-Periwinkle Vine. Interscience. http://www3.interscience.wiley.com (retrived $5^{\text {th }}$ March, 2007)

Linne, J. J. \& Ringsurd, K. K. 1979. Basic Technique for the Medical Laboratory ed.McGraw-Hall Book Company New York.

Lobert, S; Frankforter, A. \& Correla, J. J. 1998. Energetisc of Vinca alkaloid interaction With tubulin isotypes: Implications for drug efficacy and toxicity. Cell motility and the cytoskeleton 39(2): 107-121

Marton, J. F. 1977 Major Medical Plants Botany Culture and use; Charles C. Thomas, Spring-Field K.
Mattocks, A. 1968. Spectrophotometric determination of pyrrolizidine alkaloids - some improvement Analytical Chemistry 40: $1749-50$.

Mattocks, A. R. 1972. Toxicity and Metabolism of Senecio alkaloids. In: Phytochemical Ecology, ed Harborne, J. A. Academic Press, London 5: 179,182,184.

Miller, L. P. (ed) 1973. The processor product of photosynthesis, Plytochemistry Vol.I Van Mustard Reinhold Company. New York.

Pinkerton, C. R.; McDermott, B; Philip, J.; Biron, P; Andiet, C; Vandenberg, H. \& Brunat-Mentigny, M. 1988. Continuous Vincristine infusion as part of a high dose chemo-radiotherapy regimen: Drug kinetic and toxicity. Cancer Chemotherapy and Phamacology 22(3): 271-274

Raphael, S. S. 1983. Lynch's Medical Laboratory Technology $4^{\text {th }}$ ed, W.B. Saunder's Company, Philadelphia.

Ratsimamanga, R. 1980. OAU/STRC Symposium on traditional pharmacopoea and Africa Medicinal Plant, OAU/STRC Lagos, Nigeria.

Rosazza, J. P. N; Duffel, M. W.; El-Marakby, S. \& Ahn, S. H. 1992. Metabolism of the Catharanthus Alkaloids: From Streptomyces Griseus to monoamine oxidase B. Journal of Natural Products 55(3): 269-284

Siet,G; Galteau, M.M. \& Notter, D. 1980. Introductory considerations on drug effects in clinical biochemistry. "In Development in Clinical Biochemistry Volume 2: Drug effects on laboratory test results", Siet, G. Matins(Ed) Nijhoff publisher London.

Sim, S. K. 1971 Medical Plant alkaloids, University of Toronto Press, Baffalo.

Sofowora, A. 1982. Medicinal and Traditional Medicine in Africa, John Wiley and Sons Limited New York, Chicester.

Taylor, R. \& Fransworth, N. R. (Eds) 1973. The Vinca alkaloids, Dekker, New York.

Thompson, S. W. 1966. Selected histochemical and histopathological methods, Charles C. Thomas Publishers Springfield.

Vickery, M. L. \& Vickery, B. 1981. Secondary Plant Metabolism. The Macmillan Press Limited, London.

Williams, C. S. F. 1976. Practical Guide to Laboratory animals. The C.V. Mosby Company Saint Louis. 
Wilkinson, J.H. 1976. The Principle and Practise of Diagnostic Enymology. Edward Arnold, London.
Wikipedia 2006 . Catharanthus. The free encyclopedia. http://en.wikipedia.org/wiki/madagascar_periwinkle (9th November,2006. 